\title{
EDITORIAL
}

\section{EDUCAÇÃO PERMANENTE, LITERACIA E ANIMAÇÃO SOCIOCULTURAL: ALGUNS EIXOS DA PEDAGOGIA SOCIAL}

Prof. Dr. Paulo Gomes Lima

Editor Responsável

A

Pedagogia social caracteriza-se por trazer à tona não somente a proposta de reflexão sobre a realidade vivida pelos sujeitos, elemento importante, mas apenas um elemento no conjunto de ações que devem reunir agendas na proposição de intervenções sociais que resultem melhorias concretas no seio de determinado grupo ou sociedade. Outro elemento que não pode ser desprezado é a composição de planificação ou políticas públicas específicas que atendam demandas emersas por conta da diversificação e multiplicação das desigualdades sociais. Ignorar que tais disparidades existem ou não as tratar com os devidos e necessários encaminhamentos, não é somente caracterizá-las como fatalidade ou desvios de um sistema, é admitir que a perversidade é comum e o darwinismo social é plenamente justificável numa sociedade pluridiversa.

Na apresentação desse dossiê, a Professora Rosana Barros (Universidade do Algarve-Pt.), afirma que o enfrentamento de lógicas economicistas/ capitalistas, no sentido de reorientação do propósito do viver em sociedade, pode evitar consideráveis conjuntos de perversidades sociais e/ou pedagógicas, mas não de maneira ingênua e eivada somente de boa vontade. Segundo ela, a leitura do mundo deve nos fazer conscientes do papel e ações que devem acompanhá-lo para cuidar e preservar do maior patrimônio que deve transcender qualquer lógica de acumulação, ou seja, a vida humana. Por perversidade entende-se todo o escopo da violência física e simbólica que, transversalizada pelas ideologização estratificam homens, mulheres e crianças à condição de visão unilateral, naturalizando o que, de fato, não é natural e tornando comum as injustiças e desigualdades sociais.

Do ponto de vista pedagógico, à escola, às organizações não-formais e professores, cabe a abertura de tempos e espaços de discussão sobre a urgência dos cidadãos pensarem e discutirem a sociedade que tem, as oportunidades não encampadas, a percepção tão importante de que não se vive sozinho, de que a escola não é agência de reprodução, mas de transformação. Naturalmente não se pode ignorar as condições materiais socialmente determinadas que contextualizam os tempos e territórios compassados pelo capital e seu processo de internacionalização, entretanto, a tomada de consciência é um passo importante, sem a qual a corre-se o risco de justificar práticas inumanas para humanos, a materialização do funcionalismo não somente para os fatos sociais como coisas, mas a própria coisificação das pessoas. A mudança social somente no âmbito gnosiológico não é suficiente, se não for acompanhada pela dimensão ético-política, não somente acerca da forma de educar, mas do propósito da própria educação.

Tal dimensão caracteriza-se por entender a educação como processo permanente "ao longo da vida" e "para a vida" na busca de respostas para o mais importante e definidor de tudo - o tornarse humanidade, ou seja, não uma ideia reducionista de um viver social predestinado, mas uma construção que se faz em movimento e para o movimento do protagonismo do homem. Ao apropriar-se de tal vetor, as demais socializações de não-exclusão dos desiguais torna-se uma 
agenda dialética, indo para além e abrindo fronteiras para oportunizações sociais antes não previstas ou se previstas contingenciadas por discursos de diferentes interesses.

As diferentes formas de socialização do conhecimento e não-exclusão social faz-se sobremaneira pela apropriação também da palavra, entendendo-se como orientação para além de uma literacia dos já adultos ou de comunidades que começam a viver o "bios politicós" numa cadência mais ampla de letramento, mais distinta e específica na busca por estar e ser no mundo. Deste olhar vê-se que a cultura que é humana não pode e nem deve ter monopólios de pertencimento, visto que a cultura e o trabalho são eixos que, por vezes se apresentam sinônimos.

Se por trabalho se entendem as ações desenvolvidas pelo homem para transformar a sua realidade, consoante as necessidades sentidas, a natureza como um todo, por que não olhar para o conceito de cultura, parte do mesmo eixo e que o amplifica no campo conceitual e dimensional. Nesse sentido, a trilogia: educação, literacia e animação sociocultural podem ser percebidas como solicitações centrais da pedagogia social. Essa lê o mundo sem ignorar os detalhes, que podem aproximar homens e mulheres de sua humanidade. Tais discussões são aprofundadas no presente dossiê pelos colegas portugueses e que, neste momento, convido todos os leitores interessados a conhecer mais amplamente tal debate. 